Water Policy 8 (2006) 435-460

\title{
Hydro-hegemony - a framework for analysis of trans-boundary water conflicts
}

\author{
Mark Zeitoun ${ }^{\mathrm{a}}$ and Jeroen Warner ${ }^{\mathrm{b}}$ \\ ${ }^{a}$ Corresponding author. King's College, London, University of London and School of Social Science and Public Policy, \\ Department of Geography, The Strand, London, WC2R 2LS, UK. Tel: +44207836 5454, Fax: +44 2073834573. \\ E-mail: mark.zeitoun@kcl.ac.uk \\ ${ }^{b}$ Disaster Studies Group, University of Wageningen, Hollandseweg 1, 6706 KN, Wageningen, Netherlands \\ E-mail: Jeroen.Warner@wur.nl
}

Received 15 July 2005; accepted in revised form 24 October 2005

\begin{abstract}
The increasing structural and physical scarcity of water across the globe calls for a deeper understanding of transboundary water conflicts. Conventional analysis tends to downplay the role that power asymmetry plays in creating and maintaining situations of water conflict that fall short of the violent form of war and to treat as unproblematic situations of cooperation occurring in an asymmetrical context. The conceptual Framework of Hydro-Hegemony presented herein attempts to give these two features - power and varying intensities of conflict - their respective place in the perennial and deeply political question: who gets how much water, how and why?

Hydro-hegemony is hegemony at the river basin level, achieved through water resource control strategies such as resource capture, integration and containment. The strategies are executed through an array of tactics (e.g. coercionpressure, treaties, knowledge construction, etc.) that are enabled by the exploitation of existing power asymmetries within a weak international institutional context. Political processes outside the water sector configure basin-wide hydro-political relations in a form ranging from the benefits derived from cooperation under hegemonic leadership to the inequitable aspects of domination. The outcome of the competition in terms of control over the resource is determined through the form of hydro-hegemony established, typically in favour of the most powerful actor.

The Framework of Hydro-hegemony is applied to the Nile, Jordan and Tigris and Euphrates river basins, where it is found that current hydro-hegemonic configurations tend towards the dominative form.. There is evidence in each case of power asymmetries influencing an inequitable outcome - at the expense of lingering, low-intensity conflicts. It is proposed that the framework provides an analytical paradigm useful for examining the options of such powerful or hegemonized riparians and how they might move away from domination towards cooperation.
\end{abstract}

Keywords: Conflict; Conflict analysis; Hegemony; Hydro-hegemony; Middle East; Water conflict

doi: 10.2166/wp.2006.054

(C) IWA Publishing 2006 


\section{Introduction}

The purpose of this analysis is to enrich the debate on trans-boundary water conflicts - who gets how much of the water, how and why? It will be argued that control over water resources is not achieved through water wars but through a suite of power-related tactics and strategies. Groundbreaking contributions in this field include those of Frey (1993), Naff and Matson (1984), Gleick (1995), Lowi (1993), Homer-Dixon (1999) and Wolf (2002, 2004). Despite such interest, we feel that understanding remains incomplete and water conflict analysis has suffered from the under-consideration of two distinct and important theoretical issues.

The first is the existence of the varying intensities of conflict. Dozens of destructive but largely silent water conflicts lie somewhere between the much feared but non-existent "water wars" and the much lauded examples of trans-boundary water "cooperation". The reason these conflicts fall short of war and are largely silent may have much more to do with the imbalance of power between the riparians than with a perceived cooperation between them. Power relations between competing riparians, constitute the second under-considered feature of water conflicts that is a major element in this analysis.

A few key questions may illustrate the point: If Turkey - upstream on the Tigris and the Euphrates can build the GAP (Güneydoğu Anadolu Projesi, the Turkish acronym for the South-eastern Anatolia Project), what is preventing Ethiopia from doing the same on the Nile? How is it that the Palestinians living on the West Bank of the Jordan River cannot approach the river, much less pump from it?

The answers are found in power play. Power relations between riparians are the prime determinants of the degree of control over water resources that each riparian attains. Riparian position and the potential to exploit the water through hydraulic infrastructures also have some influence but are not determining except insofar as they are power related. In brief, upstreamers use water to get more power, downstreamers use power to get more water (Warner, 2004a).

By examining the implications of varying intensities of conflict and of power on water conflicts, this study suggests a conceptual framework that gives these features a systematic place in water conflict analysis. The conceptual paradigm is referred to as the Framework of Hydro-hegemony and examines the dynamics of hegemony operational at the river basin level. The concept of "hydro-hegemony" has previously been explored, for example in Warner (1992) and Williams (2002: 1192) but has not to date been thoroughly conceptualized or systematically theorized. This study attempts this task, distinguishing itself from the earlier works in at least three ways.

First, this analysis captures and refines two approaches to water conflict prediction into a single framework: (a) Yoffe et al.'s (2001) scale of water conflict event intensities and (b) Frey's (1993) poweranalytic framework. In doing this, the dynamics of water conflict are stressed, rather than attempts to predict their occurrence. Focusing in from the perspective of Wolf's (2004) broad examination of global water conflicts in terms of single or multiple "events", this study highlights the processes of conflicts that can be considered "enduring".

Through simultaneous consideration of power asymmetries and conflict intensities, precision is added to Frey's power-analytic framework, which allows statements such as "the least stable [situation] is when the downstream nation is most powerful and has most interest in water but the upstream nations also have considerable interest" (Frey, 1993: 62). That this statement has been belied by the stability of Egypt's water relations with other Nile co-riparians does not diminish the utility of Frey's framework and approach, which is picked up and developed. 
Secondly, through close investigation of the dynamics of water conflict, the strategies and tactics of hegemonic and counter-hegemonic behaviour are revealed. Better understanding of these strategies and tactics may permit their reduction or enhancement, thereby enabling change away from conflict towards more stable and secure relations. Motivations, game theory and conventional conflict resolution theories are not considered in this study, although they are identified as future areas of research.

Thirdly, this paper provides an alternative explanation for the absence of water wars. Previous explanations for the absence of water wars have proposed that market forces even out deficiencies in water-scarce semi-arid and arid countries and surpluses in temperate zones in the form of virtual water (Allan, 2001). The existence of social ingenuity (second-order social capital) - an intermediate variable between scarcity and violence - promoting adaptation rather than resource wars (Homer-Dixon, 1999) has also been argued to provide sufficient social and economic resources to avoid armed conflict (Ohlsson \& Turton, 1999). To these explanations we emphasize that the absence of war does not mean the absence of conflict, or as Waterbury (2002) says, "to suggest that war is not a likely outcome of water disputes... is not to deny the passions that international water quite legitimately arouses" (Waterbury, 2002: 10). Virtual water and second-order resources become, in this light, useful mitigators of conflictinduced water scarcity but do little to address - and in some cases may even prolong - the conflict. Furthermore, we agree with others who emphasize the point that a significant factor preventing war over water is that the actions of non-hegemonic states usually comply with the order preferred by the hegemon, whose superior power position effectively discourages any violent resistance against the order (Frey, 1993: 63; Feitelson, 2000: 350; GCI, 2000: 54; Allan, 2004).

Through examination of the competition over water resources in the Tigris, Euphrates, Jordan and Nile river basins, this analysis shows that the hydro-hegemon is always able to ensure a positive outcome - at least for itself. From its position of superior power, the hydro-hegemon may choose to enforce either a "negative" form of dominant hydro-hegemony, or a positive form of hydro-hegemonic leadership, whereby all riparians benefit. This choice can be influenced by the actions of the non-hegemon but is ultimately subject to larger political processes. The Framework of Hydro-hegemony provides a reasonably simple, comprehensive and testable structure, as well as an analytical tool for examining the options of riparians at the river basin level, moving away from domination towards partnership.

\section{Hegemony}

\subsection{What is hegemony?}

The purpose of this section is to clarify the terms "hegemony" and "hydro-hegemony". Like "water wars", hydro-hegemony is a loosely used term. It is often a convenient epithet to lambaste the behaviour of regional great powers with respect to their co-riparians, accurately or not. Thinking on hydro-hegemony is also prone to be bound up with hydraulic power politics primarily at the level of international river basins. This confusion may stem from the lack of clarity of the terms "hegemony" and "domination", which are often conflated, even in textbooks. Some of this confusion may be the result of different usage developed on either side of the Atlantic Ocean, as described in the Oxford Concise Dictionary of Politics:

"When one social class exerts power over others beyond that accounted for by coercion or law, it may be described as hegemonic... Thus the bourgeoisie was regarded as hegemonic within capitalist society by Gramsci, who believed their power depended on the permeation by bourgeois values of all organs of 
society....Among contemporary North American international relations theorists, the term has been used rather differently [in the dominative, subjugative sense of the term]" (McLean \& McMillan, 2003: 239).

There are important distinctions between these two types of rule, however. Linguistically, in Greek, a "hegemon" (from hegeisthai, "to lead") is someone who guides the way, say a torchbearer in uncharted territory. As such, hegemony can be considered as leadership buttressed by authority. In contrast, dominance is defined as leadership buttressed by coercion.

This indicates there are more subtle ways of gaining compliance from one's co-riparians than the bludgeon. Lustick (2002) draws on Ámitai Etzioni and David Held's work to identify four types of mechanisms used to produce compliance - (I) coercive (force or direct threat of force); (II) utilitarian (bribes, trades of services) and (III) normative agreement (a conscious belief that it is in the nonhegemon's best interest to comply, thereby reinforcing the legitimacy of the hegemon). A fourth mechanism, inspired by Antonio Gramsci, is that of ideological hegemony, which has it that beliefs manufactured by hegemons provide them with "an even more efficient mechanism for eliciting compliance than normative appeals to the legitimacy of state laws and decrees" (Lustick, 2002: 23) about the ordering of the world, including the role of political institutions in it. Under the influence of such ideological hegemonic beliefs, compliance with the "way things are" is only common sense and, even worse - that not complying is insane or even criminal (Lustick, 2002). Lustick further identifies the increasing efficiency of these four compliance-producing mechanisms: coercion $\rightarrow$ utilitarian $\rightarrow$ normative $\rightarrow$ hegemonic. In other words, hegemons may prefer to avoid coercive tactics to gain compliance, especially if the non-hegemons would comply unwittingly.

Theories of hegemony, then, attempt to explain how groups with power (hegemons) can maintain their pole position (control), other than through mere repression. As we shall see, and particularly in the world of water politics, violence is actually rarely resorted to. The methods of hegemony employed depend on the capacity of the hegemon to persuade subordinate actors to accept not just the hegemon's authority, but to adopt and internalize its values and norms intended to impose one solution over others. The hegemon defines the "rules of the game", establishing what are issues and what are non-issues. A situation of hegemony can therefore be (perceived as) either positive or negative, though as we shall see this is not a straightforward evaluation. This is a key point to consider, one that is developed in the following section.

\subsection{Hegemony for whom? Positive and negative forms of hegemony}

"History is what is left standing at the end of a war. That usually is the legacy of the winners. Thus history is what the victors dictate and write." (The Scientific Indian (SI), 2005).

In analysing hegemony, perceptions and position are, of course, everything - where you stand is where you sit (Allison, 1971). Writing on hegemony and on water conflict analysis in general tends to be the political science of the winners. There may be a tendency of supporters of a hegemonic power to take hegemony for granted and only use the term when they fear losing it (exemplified best in Keohane's famous After Hegemony (Keohane, 1984). On the other hand, those unhappy with existing power asymmetries are quick to dismiss undesirable manifestations of power in the water sector as "hydro-hegemonic"

That the literature is so value-laden should perhaps not be surprising. As Robert Cox (1992) observed, hegemony is supported by opinion-forming activities that design interpretations of events that are consistent with the ruling power and consequently eliminates interpretations that are inconsistent with 
the orthodoxy. We, scholars, devise theories and research that inevitably (and perhaps often unwittingly) either support or undermine hegemonies.

What is required for a deeper understanding of water conflict analysis, then, is a focus on both the benefits and the disadvantages for all states involved in a situation of hegemony. There can be said to be positively as well as negatively evaluated manifestations of hegemony on the part of the basin states. A guiding hegemon's actions may be for the good of all or most under its sphere and is associated here with a positive, leadership form of hydro-hegemony. Negative and dominative hegemonic behaviour results in an ever-growing inequity between the powerful and the weak within the hegemon's domain, associated in the Framework of Hydro-hegemony with a negative, dominative form of hydro-hegemony. Most configurations of hydro-hegemony, of course, fall somewhere between the poles of enlightened leadership and oppressive domination.

A leadership configuration of hydro-hegemony can provide international goods, such as order, stability and a greater assurance of flow. As regime theory states, hegemony can lengthen the "shadow of the future" for all involved (Baylis \& Smith, 1997). Hegemonic stability theory elaborates upon the stabilizing effects on weaker states as they come under the dominion of others (Keohane, 1982: 326; Frey, 1993: 65). This may also enable conditions that lead to proper river regulation and management, to the great benefit of the weaker state, which may enjoy a "free ride" throughout the activity. Each of these aspects may reduce transaction costs for all involved. The literature on water regimes (e.g. Kibaroglu, 2002; Jägerskog, 2003) tends to focus on the beneficial effects of cooperation, usefully counterbalancing the focus on antagonistic conflict that dominated the 1990s' "water wars" and "green wars" literature. This positive view is reinforced by Wolf's examination of global water treaties and events, which reveals a preponderance of examples of beneficial water sharing (Yoffe \& Larson, 2001; Wolf, 2004).

An established form of hydro-hegemony may be perceived as positive if the benefits (international public goods in the form of order, stable expectations and the option of free-riding) outweigh the negatives. A hegemonic power for its part may decide that the costs of assuming hegemony are too onerous, or may want to be seen to bring common benefit and try to share burdens and benefits with nonhegemonic powers.

What looks favourable from a hegemonic perspective, however, may not always be perceived in the same manner from the weaker state's vantage point. A focus on "cooperation" can hide the negative effects of power asymmetries. Asymmetries are evident in structural inequalities, the lack of control over decisions and an inequitable allocation of the resource or its benefits. All of these outcomes may result in simmering tensions with increasing potential for higher intensity conflict. The non-hegemonic power may resent its dependence on the hegemon as well as the tactics it employs to maintain its pole position ${ }^{1}$. As we shall see, such negative hegemonic configurations appear to predominate in the Middle East and North Africa (MENA) region.

In such configurations that tend toward the negative, dominative form of hydro-hegemony (as when the weaker state's "rights" to water are perceived to be denied to them by the hydro-hegemon, or flow allocations are grossly inequitable), a certain degree of conflict may be inevitable, whether or not the

\footnotetext{
${ }^{1}$ The links between the psychological aspects of resentment, non-durable settlements and renewed high-intensity conflict require further exploration to incorporate properly into the Framework of Hydro-hegemony. Good starting points for this include consideration of the effects of "relative deprivation" from conflict theory, which explains why actors rebel when they feel they did not get their "just deserts" (Delli Priscoli, 1998: 51) (see also www.hawaii.edu/powerkills/CIP.CHAP3.HTM) and the significance of "psychological satisfaction" from negotiations theory (Daoudy, 2005b: 119).
} 
conflict will manifest itself overtly. There are a number of critical scholars representing this non- or counter-hegemonic perspective - in the manner of feminists exposing male hegemony; thinkers from developing nations taking issue with "western" neo-liberal hegemony; bottom-up environmental and anti-globalisation activists and others. These critical voices remind us that the ability to define truth and meaning produces and is a product of power. The power élite seems increasingly able to impose its vision upon the other groups, a vision which those who challenge hegemony feel comes at the cost of exclusion of the hegemonised groups and their needs. Just as the mainstream discourse defined by the hegemons may go unchallenged, however, discourse that resists hegemony runs the risk of being selfreferential, like a mutual back-slapping society.

Both the proponents and critics of hegemony may be well aware of these potential biases. Whether representations and perceptions of hegemony are "accurate" or not is less important to the water conflict analyst, however, than is the development of an understanding of the processes that enable/disable the negative aspects of hegemony. Addressing these biases may allow for the depoliticization of an issue and an eventual resolution of the conflict, as was the case with South Africa, in its successful negotiations with Lesotho and Botswana along the Orange River (unlike the negotiations along the Limpopo and Incomati Rivers with Zimbabwe and Mozambique) (Turton, 2005). Further examples of water conflict analysis through the Framework of Hydro-hegemony are given throughout this paper. We turn first to consider the feature of varying intensities of conflict and the effect that this has on water conflict analysis.

\section{Intensity of conflict}

The intent of this section is to demonstrate why an understanding of the intensity of the conflict over water is important in the analysis of the outcomes of competition over the use of water resources. Apart from the military interpretation of the term, "conflict" more generally means some form of disagreement over ideas, principles or sovereignty in which the opposing forces struggle for victory. As Frey has stated, conflict exists "when one actor attempts to exert power over another to overcome that actor's perceived blockage of the first actor's goal and faces significant resistance" (Frey, 1993: 57). Conflict thus typically elicits concepts of marking out territory, establishing limits, of a victor and - on the flip side - a loser and of the reciprocal suffering.

Conflict comes in a vast range of types and degrees of intensity. Conflict between states has been appreciated and theorized by schools of conflict analysis, conflict resolution and humanitarianism (see ICRC, 1994). The NATO conflict-development scale of 1999, for example, identifies five stages in the development of conflicts:

Durable Peace $\rightarrow$ Stable Peace $\rightarrow$ Unstable Peace $\rightarrow$ Crisis $\rightarrow$ War (NATO, 1999: 98, after NATO, 1999).

A more precise conflict intensity scale was developed by Edward Azar for his Conflict and Peace Databank (Yoffe \& Larson, 2001). The resultant Water Event Intensity Scale (Table 1), which is subsequently amended by these authors to address water conflicts in particular as a contribution to Wolf's Basin at Risk project, precisely defines a very broad range of intensities and is a useful tool for water conflict analysts.

Yoffe et al's Water Event Intensity Scale demonstrates first that each of the different levels of intensity of conflict has very different implications in terms of international relations. Consider for example, the difference in the effect on relations provoked by a "formal declaration of war" with those provoked by 
Table 1. Water event intensity scale.

\begin{tabular}{ll}
\hline Scale & Event description \\
\hline 7 & Voluntary unification into one nation \\
6 & Major strategic alliance (International Freshwater Treaty) \\
5 & Military, economic or strategic support \\
4 & Non-military economic, technological or industrial agreement \\
3 & Cultural or scientific support (non-strategic) \\
2 & Official verbal support of goals, values, or regime \\
1 & Minor official exchanges, talks or policy expressions - mild verbal support \\
0 & Neutral or non-significant acts for the inter-nation situation \\
-1 & Mild verbal expressions displaying discord in interaction \\
-2 & Strong verbal expressions displaying hostility in interaction \\
-3 & Diplomatic-economic hostile actions \\
-4 & Political-military hostile actions \\
-5 & Small scale military acts \\
-6 & Extensive war acts causing deaths, dislocation or high strategic costs \\
-7 & Formal declaration of war \\
\hline
\end{tabular}

Yoffe et al. (2001: 71).

a "mild verbal expression". Secondly, the scale demonstrates that even the less-intense conflicts, are still forms of conflict. In other words, the absence of war does not mean the absence of conflict.

The Conflict Intensity Frame illustrated in Figure 1 attempts to capture and exemplify these different viewpoints, providing three very broad categories: "no significant conflict", "cold conflict" or "violent conflict". The examples selected are not water focused.

The Conflict Intensity Frame reveals not simply that different conflicts vary in intensity, but that the same conflict can undergo various degrees of intensity through time, as in the case of US-Iraqi relations

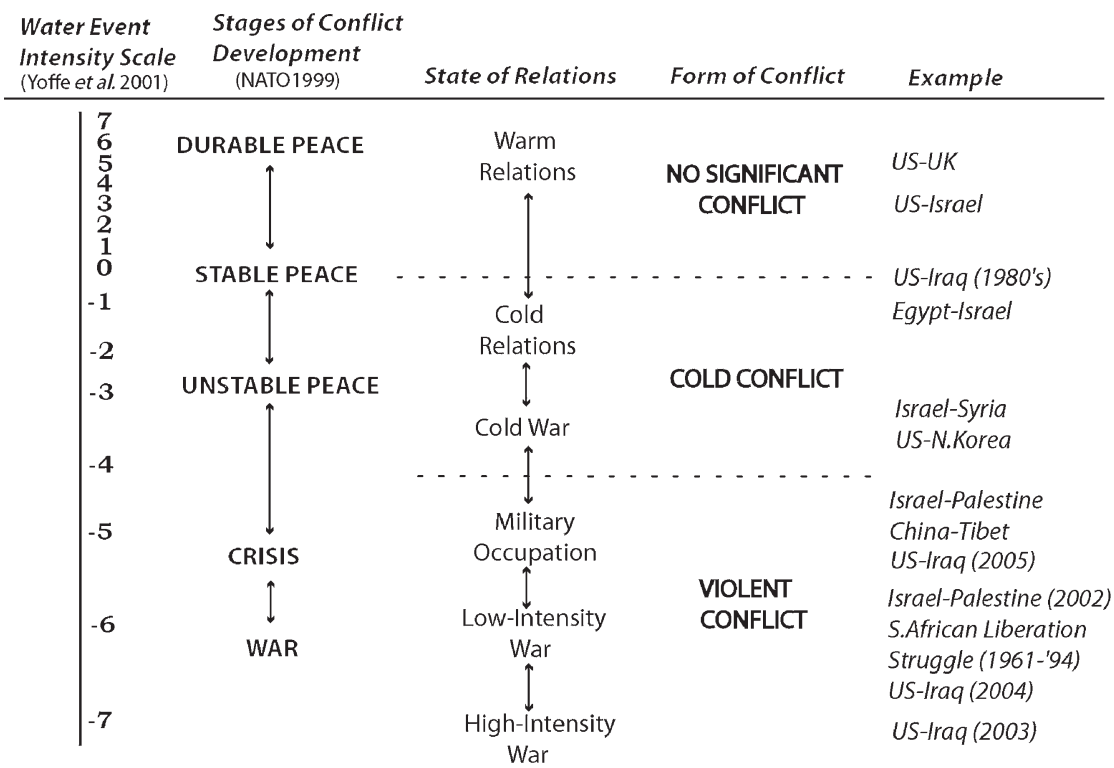

Fig. 1. Conflict Intensity Frame. 
since the 1970s. What the scales cannot show or account for are the effects of power asymmetries in determining the phases of changing intensity of the conflict. As will be shown, however, the potential positive and negative consequences of the asymmetry should not be ignored.

\section{Power}

This section attempts to shed some light on how the diverse features of power may be relevant to transboundary water conflict analysis. The nature of the act of engaging in competition over trans-boundary water resources, particularly when water is scarce, reveals each competitor's strengths and weaknesses. Barring luck, fate or exception, it is the more powerful, hegemonic side that achieves and maintains the upper hand in their control. A precise understanding of the concept of power, as it applies to international relations is one of the classic unresolved issues of political science and is touched upon only briefly here.

Dahl has defined power as A's capacity to make B do what B would otherwise not do (Dahl, 1965). While violence, intimidation and coercion are expressions of power that come to mind, power can also be wielded, observed and measured by counter-intuitive measures. To frame these ideas, Daoudy (2005a) and Turton (2005), if in different terminology, both point out two broad forms of power: puissance and pouvoir. Puissance is potential power, power as might, such as the physical wherewithal power to explode an atomic bomb, pouvoir is actualised power, the authority or 'powers' to stop the rocket being launched. This 'pouvoir' meaning can be actualised at three levels, each level progressively more profound and hideen than the last, as famously identified by Lukes (2005 [1974]).

The most visible, first dimension of power lies with the state able to possess and to mobilize capabilities, including military might, economic strength, modes of production, access to knowledge (Strange, 1987: 132), as well as political support and the rather more enduring features such as riparian position, size and value of territory, and so on.

The second dimension of power refers to control of the rules of the game. This type of power is analogous to Bachrach and Baratz' characterization of the "second face of power", which consists essentially of stripping the weaker party of the ability to choose between compliance or noncompliance with the stronger party's commands (Lukes, 2005: 11). The type of power a baby may have over her mother is an example of the power to set the agenda ${ }^{2}$. Furthermore, a weakness in bargaining power that a state has in one sector may be compensated for by a relatively high level of the second dimension of power in another sector. Daoudy (2005b) convincingly demonstrates how downstream statesmay actively leverage this type of power into a bargaining strategy of "issue-

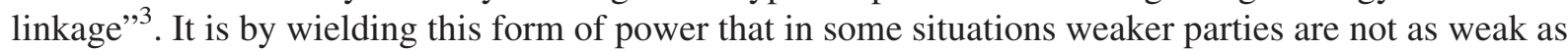
they may appear to be or perceive they are (Daoudy, 2005a). Dellapenna (2003: 289) points out how a state may use a reference to international law to gain a sense of legitimacy for customary practices, thereby increasing its bargaining power for continued extraction from a river, for example.

\footnotetext{
${ }^{2}$ By drawing on the fading ideology of Arab brotherhood, for example, Iraq may find enough bargaining power to prevent Syria (if not Turkey) from undertaking projects on the Tigris River without prior notification.

${ }^{3}$ Syria, for example, found itself with perhaps unexpected bargaining power in the form of issue-linkage when it benefited from the environmental and Kurdish human rights movements directed at the financing of Turkey's Ilisu dam in 2001 (Daoudy, $2005 \mathrm{~b}$ : 119). The issue-linkage feature of bargaining power reveals a further weakness that structural power has in countering it structural power has a relatively lower fungibility, resulting in operational constraints (Evans \& Newnham, 1998: 188).
} 
In his seminal 1974 work Power - A Radical View, Lukes asked "how do the powerful secure the compliance of those they dominate - and, more specifically, how do they secure their willing compliance?" (Lukes, 2005: 12 (original emphasis)). Charles Tilly touches upon this third form of power when heclaims that "as a result of mystification, repression or sheer unavailability of alternative ideological frames, subordinates remain unaware of their true interests" (Tilly, 1991: 594 cited in Lukes, 2005: 10 (emphasis added)). Strange (1994) herself identifies a third level of power exercised through what she terms the knowledge structure: "At this level, the strong implant their ideas, even their self-serving ideology, in the minds of the weak, so that the weak come to sincerely believe that the value-judgments of the strong really are the universally right and true ones" (Strange, 1994: 176) ${ }^{4}$. Power theory and hegemony theory converge to a certain degree at this point, with the concept of power-over-ideas possessing features fundamentally similar to Lustick's fourth compliance-producing mechanism, ideological hegemony.

Through exertions of these three forms of power, a hegemonic actor has considerable ability to (re)write the rules of the game. A hegemon's material power (technology, economic clout) undergirds its firstdimensional power to represent the world in a particular way, and find these representations accepted and reproduced by those not in power. The second and third dimensions of power are then more readily put to use. The effect can be considerable - "Those in power within the institutions of the hegemonic state become the deans of world politics, the administrators, regulators and geographers of international affairs" (O'Tuathail \& Agnew, 1999: 82). The key to power thus rests with the hegemon in the order that it has established; as we shall see in the following sections, this is one of the main effects of an asymmetry of power.

\section{Hydro-hegemony}

This section combines the previously-discussed concepts of power, hegemony and intensity of conflict to develop a single framework to facilitate the analysis of water conflict.

\subsection{Competition or Cooperation: Interaction over transboundary water resources}

It is useful to view riparian interactions over transboundary water resources as lying somewhere between the extremes of genuine cooperation and cut-throat competition. For the purpose of this analysis, it is accepted that each riparian will act to maximize their objectives with the resource, however these may be perceived. Where water is physically scarce, the interaction could be expected to be a competition fought for control over a greater volume of flows. Where there is an abundance of water, one riparian may seek control over the flows for hydropower while another may seek control for flood-management purposes. In certain cases, control of the resource may be relinquished to achieve politically-afiliated nonwater goals. Regardless of the motives for control of the resource, both the strongest and the weaker riparians will find themselves engaged in any of three situations. Control can be either (a) shared (meaning some form of cooperation exists), (b) consolidated in the stronger riparian's favour (where cooperation is minimal, and the competition is shut-down) or (c) contested (when the competition is at its fiercest). As we

\footnotetext{
${ }^{4}$ In this analysis Strange is drawing implicitly on the "knowledge is power" work of Foucault. Extensive work on this subject has been considered, partially through the following texts: (Barnett, 1999; Horrocks, 1999; Allan, 2001: 182; Burawoy, 2003; Chomsky, 2003; Selby, 2003a).
} 
see, the form of interaction can be characterised with a distinct nature (i.e. cooperative or competitive), and a particular form of hydro-hegemony. This situation is represented in Figure 2.

The most stable situation in terms of riparian relations is likely to be when the riparians share control of the resource, as the case whereby the hegemon has negotiated a water-sharing agreement that is perceived positively by all riparians. This can be taken as the 'positive/leadership' form of hydro-hegemony. Allocations or benefits resulting from such agreements could be based on customary international water law or on the definitions of "equitable and reasonable use" as defined by the 1997 United Nations Convention on the Non-Navigational Uses of International Watercourses (UN ILC, 1997). At the other hand of the spectrum, the stronger competitor may seek to attain and consolidate maximum control of water resources, through unilateral action. Such 'negative/dominative', exploitative configurations of hydro-hegemony inevitably lead to the weaker competitor having less control. The dominative form of hydro-hegemony is thus associated with induced relative scarcity for the weaker riparians and unstable hydro-relations. Particularly when the riparians are roughly equal in power, the established control of the resources may become contested, with the resulting competition leading to either a reversal of the dominative form of hydro-hegemony or progression towards a leadership form.

The focus of this study lies on an examination of three river basins where there is a clear imbalance in power, and the interaction over resources is considered competitive, but stifled. The Tigris, Euphrates, the Jordan and the Nile rivers - where Turkey, Israel and Egypt are the hydro-hegemons - is instructive in revealing the various means used to establish a negative/dominative form of hydro-hegemony. Figure 3 shows at the lower levels the "coercive resources" available and the tactics used to exert power in riparian circumstances, whether for leadership or doiminative outcomes. Classified into Lustick's frame of increasingly efficient compliance-producing mechanisms, these diverse tactics are deployed to achieve three strategic outcomes - resource capture, integration or containment. The competition occurs within the broader international political context, which is characterised by a weakness of law and ever-changing initiatives and alliances. Definition and elaboration of each strategy and tactic follows.

\subsection{Water resource control strategies}

Resource capture is said to occur when "powerful groups within a society... shift resource distribution in their favour" (Homer-Dixon, 1999: 177). A resource capture strategy may be analagous to what Waterbury terms 'active unilateralism', "whereby a riparian, in the absence of formal understandings, moves ahead with projects that affect the flow or quality of the resource" (Waterbury, 1997: 279). As such, resource capture is typically carried out by creating 'facts on the ground' that enable control over access to the resource. These may include land acquisition, land annexation or the construction of large-scale hydraulic works. In cases where a river forms the border between competitors, diversion dykes may satisfy one competitor's demand, leaving the other dry; in the case of trans-boundary groundwater, high-capacity deep wells and pumps can drop the water level out of reach of the competitor's shallower, lower capacity wells located on the other side

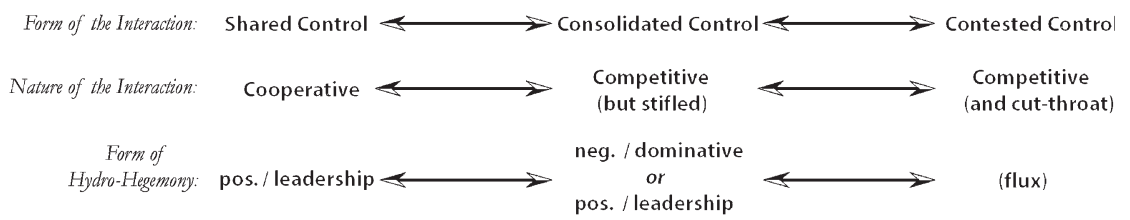

Fig. 2. Continuum of Forms of Interaction over Transboundary Water Resources. 


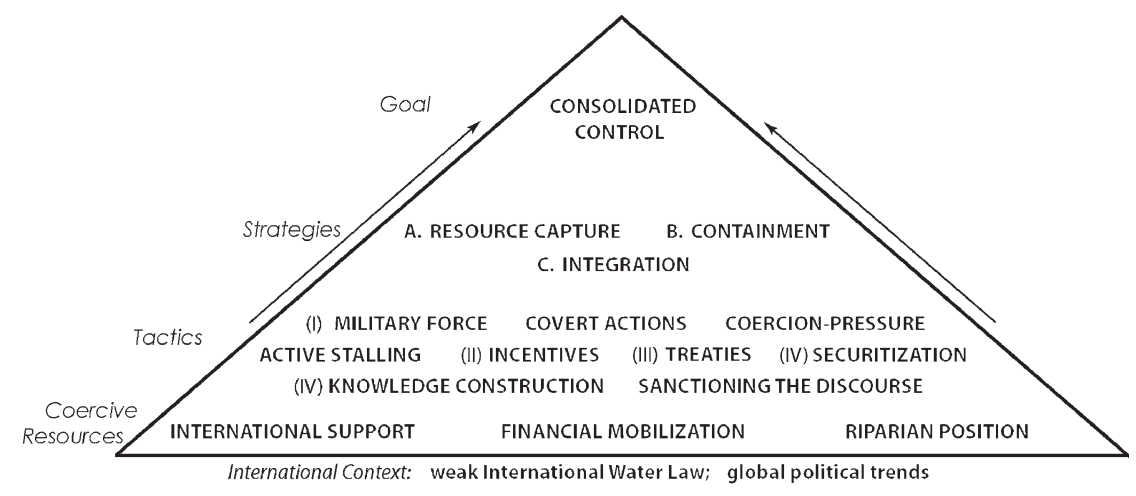

Roman numerals relate to Lustick's (2002) classification of increasingly efficient complianceproducing mechanisms: (I) coercion, (II) utilitarian exchange, (III) instigating normative agreement and (IV) inducing ideologically hegemonic beliefs. The list is non-exhaustive.

Fig. 3. Water Resource Control Strategies and Tactics.

of the border. A state with the ability to plan, construct and operate large infrastructure projects has the physical ability to change the hydrogeology of the resource, thereby creating new hydro-strategic and hydropolitical realities. Turkey's multi-dam GAP project (Lorenz \& Erickson, 1999; Warner, 2004a: 16), Israel's National Water Carrier (Trottier, 1999, Feitelson, 2000; Allan, 2001) and Egypt's High Aswan Dam (Waterbury, 2002; Takele, 2004) are prime examples of large infrastructure enabling the capture of resources and significantly altering the nature of the competition over water to the advantage of the constructor.

Faced with the demands of a competitor and aware of customary law concerning the sharing of transboundary resources, the hydro-hegemon may find it more efficient to co-opt its weaker competitors, rather than trying to ignore or discredit their claims. Unlike the unilateralist resource capture strategy previously discussed, this containment strategy requires engagement with competitors. Any such bilateral or multi-lateral strategy may seek either to integrate the competitors or to contain them in as asymmetric a position as possible, through the use of coercive, utilitarian, normative or hegemonic compliance-producing mechanisms. In following a containment strategy, the stronger state would seek to influence the weaker riparian(s) towards compliance with its preferred order of affairs through a variety of 'Type III' normative or 'Type IV' hegemonic mechanisms and applications of the three dimensions power. The drafting and signing of a treaty favouring the hydro-hegemon is the preferred tactic when employing a containment strategy, such as the bilateral treaties of Israel-Jordan in 1994 (Dombrowski, 1998: 99) and Israel-Palestine in 1995 (Selby, 2003a).

An integration strategy, on the other hand, would seek to encourage compliance with agreements through incentives, through the use of 'Type II' utilitarian mechanisms. Water is particularly suited to such a strategy, precisely because of the wide variety of benefits that can be drawn from its various uses. By "building-in" to a regime benefits that may be more equitably distributed than the water itself, a hydro-hegemon may concede some of the privileges offered through its relative power ${ }^{5}$. In so doing, all

\footnotetext{
5 The main differences between a benefit-sharing and a water-sharing regime is that the "pie" can be made bigger and that more "creative" agreements can be crafted. The point of this framework's power-analytic approach must be retained however: power, in all of its forms, will be active in the distribution of benefits just as it is active in the distribution of flows. This again raises the issues of a hegemon's motivations and the effects of relative deprivation, both of which merit much deeper analysis than is permitted by space here.
} 
of the riparians under its domain move to the left of Figure 2, towards interaction characterised by "shared control". The resultant hydro-hegemonic configuration would be more likely to be perceived by all riparians as positive. This is arguably the case along the Orange River, in southern Africa (Turton, 2005), but not of the Nile, Jordan or Tigris and Euphrates rivers.

\subsection{Tactics and coercive resources}

Exemplification (albeit non-exhaustive) of the inventory of devices used to carry out the strategies of Figure 3, in Middle East and North African water conflicts, follows. The manipulation of time (Daoudy, 2005a), the "cost of no agreement" and the ability to execute strategies in silence (Greco, 2005) are examples of important and effective tactics that are not dealt with in this paper ${ }^{6}$.

In order to deploy these tactics effectively, riparians must draw upon the political support of their allies and the collective ability to mobilize funds. These "coercive resources", vary with changing global political currents and are exploited through the weaknesses of the international regulatory context, particularly the absence of effective international law. There follows a discussion of the tactics evident in the hydro-politics of the Middle East and North Africa.

\section{Tactics \\ I Coercive compliance-producing mechanisms}

Military force. Military force is rarely used in water conflicts, and usually then only as a last resort (Wolf, 2004). It is nonetheless extremely effective in the implementation of a resource capture strategy. The bombing of a dam, political or security apparatus has very visible, immediate and undeniable effects on the competition, as evidenced by the outcome of the violence between Syria and Israel in the 1950s and $1960 \mathrm{~s}^{7}$.

Covert action. A competitor (or protector, in the case of the Iran-contra affair) may engage in undercover operations aimed at weakening the political, military or hydraulic apparatus of its competitor, or make a pact with those who will. Consider Egypt's motives behind its support for the Eritrean Liberation Front and Somali irredentism (Dinar, 1999; Takele, 2004) and Syria's support (until 1998) for the Kurdish Workers' Party (PKK), in relation to the GAP project (see MacQuarrie, 2004).

Coercion-pressure. This may be the most commonly used tool used to achieve any of the three water resource control strategies. Threats (military action, economic sanctions or political isolation) are readily

\footnotetext{
${ }^{6}$ Greco (2005), for example, identifies Jordan's "quiet" pumping of the Disi aquifer shared with Saudi Arabia as a tactic of establishing 'prior use' of the resource, thereby gaining a form of legitimacy and power.

${ }^{7}$ This refers to the case of Syrian-Israeli fighting over water development projects on the upper Jordan River in 1951 and 1965 (Trottier, 1999: 52). In both cases, the attacks were effective in so far as they permanently stopped the construction of the projects, contributing in the process to larger political tensions that led to the 1967 June War and Israel's capture of Syria's Golan Heights. Although not motivated primarily by hydraulic concerns (Wolf, 2000; Medzini, 2001) the effective waterresource capture that came with the 1967 capture of the land allowed Israel greater control of the upper Jordan River (el Musa, 1997: 218) as well as the aquifers transboundary to the West Bank and Gaza, thereby marking the beginning of the "Israeli hegemony era" (Feitelson, 2000: 350).
} 
deployed by one state against the other to ensure, for example, that the latter drops its claims over the resource, or at least stops creating a (potentially compromising) row. As a politically "invisible" tactic, it can also regularly be deployed by the stronger party, which can downplay the effects of the coercion and de-politicize issues - a situation endured by the weaker party. Coercive resources available include trade embargoes, diplomatic isolation, threat of military action, espionage and propaganda. Waterbury describes the effect of some of these measures employed by Egypt against Ethiopia:

"Egypt is by far the most powerful riparian. . . it still has formidable veto power. It has been successful in imposing the status quo for four decades and it will surely shape any change in the status quo. It cannot dictate terms, but no riparian, including Ethiopia, will seek, let alone welcome, confrontation with Egypt when its well-known national interests are at stake." (Waterbury, 2002: 167).

\section{Utilitarian compliance-producing mechanisms}

Incentives. The coercive "sticks" of 'Type I' compliance-producing mechanisms may well be combined with compliance-encouraging "carrots". Incentives for compliance with a hydro-hegemon's preferred state of affairs are in fact the direct opposite of the coercive mechanisms mentioned above, including trade incentives, diplomatic recognitions, military protection, and so on. Mutually beneficial "shared interest" water projects have proven an effective incentive for cooperation that can lead to more stable hydrorelations. Examples of this positive-sum hydro-hegemonic configuration include the proposed all-Nilotic electricity grid between Uganda and Egypt (Waterbury, 2002) as well as the irrigation line threading through the oxbows along the Orange River between South Africa and Namibia (Heyns, 2005b).

\section{Normative compliance-producing mechanisms}

Treaties. Particularly during or following periods of rapprochement, the signing of an agreement to institutionalize the status quo may be a tool used to the hydro-hegemon's advantage. The signing co-riparian (e.g. Sudan in 1959) may be in agreement that the treaty has sufficient benefits to justify signing. Treaties can transform an agreement between two parties into an instrument of leverage for the stronger side, however. A number of weaknesses inherent in treaties make them particularly well-suited for exploitation towards a negative outcome of hydro-hegemony, through the execution of a containment strategy:

- As with any international law or accord, a treaty is not easily enforceable. Violations of the spirit or letter of the treaty by the stronger side are answerable only to structures within the existing balance of power.

- The treaty can be structured by the more powerful riparian to reflect existing inequalities and then coercion may be used to get the weaker to sign. Cases where a stronger party cuts such a "deal" with a weaker party may be considered to be agreed to under duress. The Egyptian-Ethiopian treaty of 1906 is an example (Waterbury, 2002), while Fischhendler (2004: 293) exposes several issues unresolved by the annex on water forming part of the 1994 Peace Treaty signed by Israel and Jordan in 1994.

- Bilateral agreements can effectively rule out participation of a riparian not signatory to the treaty, thereby pre-empting the rights of the non-signatory states and once again leaving the issue unresolved. As Green Cross International has noted:

"Fragmented attempts at resolving water disputes, which exclude other basin states or important sectors of water users, have seriously compromised chances of achieving long-term solutions. Examples 
of such attempts are all too common, including the 1994 peace agreement between Israel and Jordan, which left out the Palestinians, Lebanon and Syria and the 1959 agreement between Egypt and Sudan over the Aswan High Dam, which ignored all other Nile riparian states, most importantly Ethiopia" (GCI, 2000: 59).

\section{Hegemonic compliance-producing mechanisms}

Securitization. "Securitization" is the speech act that legitimises a state to take exceptional measures over an issue by propelling it into the realm of security (Buzan et al., 1998) ${ }^{8}$. Promoting a project to a national-security concern equates criticism to treason, thus silencing critical voices in the bureaucracy and maintaining a form of hegemonic thought control. Securitization facilitates politicians' ability to "construct knowledge" around any water-related issue to fit other political interests. This approach is an example of what Plato refers to as a "noble lie" and reinforces Gramsci's proposition that beliefs are held by people who do not experience them as beliefs (Lustick, 2002). In the name of national or water security, for example, Israel threatened to attack Lebanon over the relatively minor Wazzani springs project in 2002, while diverting its public's attention away from much more serious water-management issues (Newman, 2002; Zisser, 2002; Zeitoun, 2005).

Knowledge construction. Constructed knowledge can be considered a variant of "sanctioned discourse", which Feitelson (1999) defines as "a normative delimitation separating the types of discourse perceived to be politically acceptable from those that are deemed politically unacceptable at a specific point in time." (Feitelson, 1999; see also Allan, 2001: 182). "Received wisdom", "conventional wisdom" and "manufactured consent" (Chomsky, 1992) may be other variants, from which Lustick's "ideologically hegemonic belief" is an application. The concept has it that a full understanding of an issue, such as competition over water, may be as much guided by popular beliefs - accurate or inaccurate - as guided by science-based knowledge. According to Cascao (2005), the confusion this creates enables Egypt, for example, to give different perspectives on its hydro-situation to its own people, to international donors and to its riparian competitors or friends, creating more room to manoeuvre by reducing apparent external pressure.

Sanctioned discourse. The concept of sanctioned discourse evolved from the world of water policy research (Allan, 2003: 2), with Charles Tripp's emphasis on the constraints imposed upon those who may wish to speak or think outside of the discursive hegemony (Allan, 2001: 182). Accepting the premise of knowledge construction, Hajer notes that the process of alternative discourses contending results in actors securing support "for their definition of reality" (Hajer, 1997: 59). The process results in a prevailing discourse heard above the others - the sanctioned discourse, by definition endorsed by the more powerful side.

Used hand-in-hand with knowledge construction, a tactic of sanctioning the discourse in the world of water conflicts may serve to veil certain aspects of riparian relations (e.g. inequitable distribution) while emphasising others (e.g. the merits of technical cooperation). The official Egyptian discourse promoting the benefits of the Nile Basin Initiative, like the official Israeli discourse of cooperation through the Palestinian-Israeli Joint Water Committee, for instance, are regularly heard at international fora and in

\footnotetext{
${ }^{8}$ See e.g. Turton (2003), Warner (2004a), Warner (2004b), and Greco (2005) for application to the water sector.
} 
the journals. These discourses effectively drown out opposing viewpoints presented less frequently and eloquently by Ethiopian or Palestinian civil society outside the halls of power. The 'cooperative' tone of the more powerful actors' discourse can be expected to sit well with the international donor community, which thereby assists in sanctioning the prevailing discourse while excluding the alternatives. This point will be emphasised in the following section.

Coercive resources. Having identified the manoeuvres that riparian states may follow to obtain and maintain positive-sum or negative-sum hydro-hegemonic configurations, we turn now to examine the context and factors that give the more powerful state its competitive edge. These power resources underpin the strategies and tactics of Figure 3 and are set within an international context beset by inequalities such as global political trends, partisanship and the absence of a universally-recognized and enforceable international water law. The international system yields unequal opportunities for generating funds and support, just as the physical realities of riparian position offer advantages to one competitor over the other.

While international law and in some cases donor conditions aim to equalise power discrepancies, hydro-hegemonic states are largely able to resist and/or avoid the pressure from these sources. The power resources that enable them to do so are numerous and include international support, the ability to mobilize funds and general "human capital", such as the level of education and technology in-country. Brief discussion of two power resources follows.

International support. Having powerful friends can be a very efficient source of power. Apart from securing access to funds for water infrastructure, enjoying a favoured political position globally can directly result in a favourable position in the competition over water. This is similar in concept to Buzan's description of outsider-imposed changes upon an indigenous security complex, a dynamic which he calls "overlay" (Buzan et al., 1998: 12). That Egypt and Israel remain river basin hegemons and regional superpowers, for example, is at least partly associated with the fact that they have been the two largest recipients of US financial and political support ${ }^{9}$, with Turkey lagging not far behind (CRS, 2004).

Furthermore, "the scope of [a] conflict cannot really be grasped without taking the colonial legacy into account" (Warner, 2004a: 13). Colonial Britain's favouring of Egypt over the Sudan in 1929 (Waterbury, 2002; Adam, 2004), for example (or its favouring of Egypt and the Sudan over Ethiopia, Uganda and other Nile riparians in 1959) led to treaties signed between these parties being not simply unbalanced against the upstream riparians but excluding them altogether (Dinar, 1999; Takele, 2004; Cascao, 2005). Similarly, at the time of the regional hydraulic imperative in the West, Iraq was favoured over Turkey by the powerful British in the Tigris and Euphrates basins. The effect of new alliances formed with changed governments is also significant, such as US support of Iraqi interests (water or otherwise) following the second Gulf War.

Financial mobilization. A state desperate for financial assistance and without recourse to alternative funding is forced to follow the donor's regulations and does not have the option of following a unilateral "resource capture" policy. Setting and implementing unilateral water infrastructure projects and policies

\footnotetext{
${ }^{9}$ Prior to US funds spent in post-Saddam Iraq after 2003.
} 
is a luxury afforded to (a) relatively rich states (for instance, South Africa), (b) those with allies outside the established donor system (for example Egypt's recourse to Soviet Union funding in the 1960s, or China's recent hydraulic investments in the Gezira Irrigation Scheme, in the Sudan) and (c) those willing to bleed their coffers dry, if need be, to realise their plans (e.g. Turkey, with the GAP project).

Ethiopia, for example, is far more likely to be restrained from development than Egypt, which "continues to fund and support projects of the Nile Basin Initiative, which they first proposed in 1995, that leaves them free to develop their extensive deserts in Sinai and the New Valley." (Collins, 2003: 30). Furthermore, not only can hydro-hegemonic states with powerful friends, deep pockets and determination go the distance (Frey, 1993: 64), they can also exploit the mutually dependent nature of lending institutions and loan recipients. As Tony Allan noted during the 1st Hydro-hegemony workshop ${ }^{10}$, "the World Bank may need Egypt more than Egypt needs the World Bank". Clearly, donor and bank funding is not necessarily neutral or equitably distributed. "Their policies and priorities reflect an unstable balance of the professional preference of the experts who staff them with the national objectives of their member states. Their analyses and recommendations are the product of bargaining and compromise between these constituents and the richer contributing nations can steer the interventions." (Waterbury, 2002: 26).

Riparian position. The physical nature of water until this point has been admittedly downplayed. The effects of gravity and geography must be given their due consideration. Water conflict theorists Frey and Naff did not lose sight of this dynamic when they observed that from an upstream position: "one can usually take actions that confront downstream competitors with faits accomplis, the alteration of which is far more demanding than the original action. Diversion, overuse, contamination and flow delay are tactics available in accordance with one's position on the riparian totem pole. (Frey \& Naff, 1985: 78). Riparian position is perhaps the most static form of coercive resource, and one that is essentially outside of the struggle for a better position in the balance of power between States. Political entities blessed with such a coercive resource are not likely to have it eroded, short of territorial conquest by another.

\subsection{Power asymmetry and the limitations of international law}

It is argued that the balance of power ultimately determines riparian interactions over shared resources. This may be because in cases where one state is undeniably more powerful than its competitor, the more powerful state has available to it the full range of strategies and complianceproducing mechanisms, as well as a larger reserve of the "coercive resources" shown in Figure 3. The weaker state has much fewer options available to it and a narrower field of manoeuvre (i.e. fewer degrees of freedom) within each of these options.

The underdeveloped "teeth" of the international law system are one option theoretically available to the weaker state. The fact that there is little or no universally recognized international water law remains a major problem in international hydro-relations. As Susan Strange has noted, "the outcomes in an international society that has no legitimate, overriding authority are necessarily determined by relationships of power and far less by law, custom or social convention than is the case within national societies". (Strange, 1987: 123).

${ }^{10}$ Held 21-22 May 2005 at King's College London, London, UK. 
Thus, while legislative processes are in train and norms are emerging that encroach on sovereignty and encourage sharing (i.e. "equitable and reasonable use", "no harm"), the 1997 United Nations Convention on the Non-Navigational Uses of International Watercourses is in and of itself insufficient to ensure implementation of these principles (GCI, 2000: 44). Egypt's launching of the Toshka reclamation project in 1997 can be considered to be an example of flouting of the spirit, if not the letter, of the UN Convention (Collins, 2003: 22). These same principles may even serve to act against the interests of the weaker states, as in the position of stifled development that exists in Nepal, upstream on rivers contended with the much more powerful India (Subedi, 2005), a situation mirrored in Ethiopia.

Benvenisti (2002) sums up the relationship between trans-boundary water resources, sovereignty, power and law:

"The two basic building blocks of the global political and legal environment - the concept of sovereignty and the allocation of jurisdiction by political borders - have joined forces to preclude an efficient and sustainable use of trans-boundary resources... Absent legal constraints and well-defined rights, relatively powerful downstream states began resorting to economic and military threats to elicit cooperation, while relatively weaker riparians acquiesced and actual practice reflected the regional military balance of power." (Benvenisti, 2002: 22-24).

\subsection{Assessing hydro-hegemony: combining power, position and potential}

Naff and Matson (1984) (quoted in Medzini, 2001: 14) propose that the "power ratio" between competing riparian states is based on each state's (a) overall economic/political/military power, (b) overall technological power and (c) selective geographical position. In other words, a measure of the degree of hydro-hegemony achieved by a riparian is best evaluated through a review of their power position, riparian position and resource exploitation potential. These are represented graphically in Figure 4 and will be briefly elaborated below.

The examples taken from the river basins of the MENA region show that power (in each of its three dimensions) is the prime determinant enabling the successful execution of the water resource control

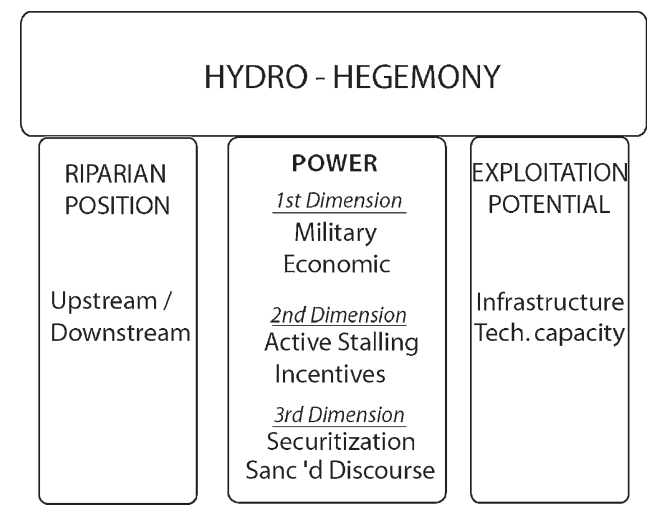

Fig. 4. The pillars of Hydro-Hegemony. 
strategies of Figure 3. A better relative position in the other determining components - riparian position and exploitation potential - may also inform outcomes, however.

This proposed form of measurement provides a "snapshot" of current levels of hydro-hegemony achieved - see the comparison of levels of hegemony along selected MENA river basins for example, in Annex A. The weaker state can be expected to have little or unconsolidated control as a function of the water-sharing regime established by the hydro-hegemon. The effects of this asymmetry on the intensity of the conflict and on the outcome of the competition for water are not difficult to predict.

\section{Some outcomes of hydro-hegemony}

"It is the oppressor who defines the nature of the struggle." (Mandela, 1994).

The purpose of this final section is to reveal the combined effect of the interplay between power, water and intensities of conflict. It will be shown that the nature of interaction over water resources and form of hydro-hegemony established is determined by the hydro-hegemon. The hydro-hegemon seeking to establish a positive/leadership hydro-hegemonic configuration will follow any or all of the three water resource control strategies to ensure cooperative interactions under its guidance. Similarily, a hydrohegemon intent on maintaining sole control over the resources will stifle competition through a number of means, resulting in a dominative form of hydro-hegemony and a lingering (and usually "silent") conflict. The hydro-hegemon determines the nature of the interaction, and to what extent the benefits derived from the flows will also extend to the weaker co-riparians.

Along the shared resources of the Nile, Tigris, Euphrates and Jordan Rivers, each of the regional hegemons (Egypt, Turkey and Israel) have put their power in all three dimensions to use to determine varying intensities of dominative forms of hydro-hegemony. This holds true even for those states in geographically weaker downstream or mid-stream positions, like Egypt and Israel.

Along the Euphrates, Iraq and Syria seek alternatives and support as Turkey continues its unilateral engineering projects (Daoudy, 2003). Uganda, Ethiopia and the Sudan compile their lists of stalled projects for Nile development as Egypt continues with its unilateral project at Toshka. Along the Jordan River, Israel controls $90 \%$ of the shared surface and groundwater resources; Palestinians, who have no other alternative sources to develop, control 10\%, despite the 1995 agreement forming part of the Oslo II accords whereby Israel explicitly recognized Palestinian water rights (B'tselem, 1998; Frederiksen, 2003). In each of these cases the lion's share of the water or its benefits is secured for the hydrohegemon, with apparent disregard for international customary water law sharing principles.

The Hydro-hegemony Framework of Figure 5 combines Figures 1 and 2 and summarizes the analysis between the form of hydro-hegemony established, the positive and negative outcomes of the distribution of water resources and the resultant intensity of conflict.

Figure 5 may be tested by considering the case of the previously-mentioned Orange River in southern Africa. In choosing to play the leadership role at the river basin level, South Africa has attempted to create a positive-sum hydro-hegemonic configuration through the incentive of benefits-sharing - by definition, the execution of an "integration" strategy through utilitarian compliance-producing mechanisms. The benefits are identified and negotiated between river basin members Botswana, Lesotho and Namibia through the SADC protocol on shared watercourse systems, arguably resulting in a stable situation and an "equitable" distribution of the benefits (Turton, 2005). The Namibian perspective adds texture to the picture - complaints of coercive tactics through the SADC have been voiced by at least 


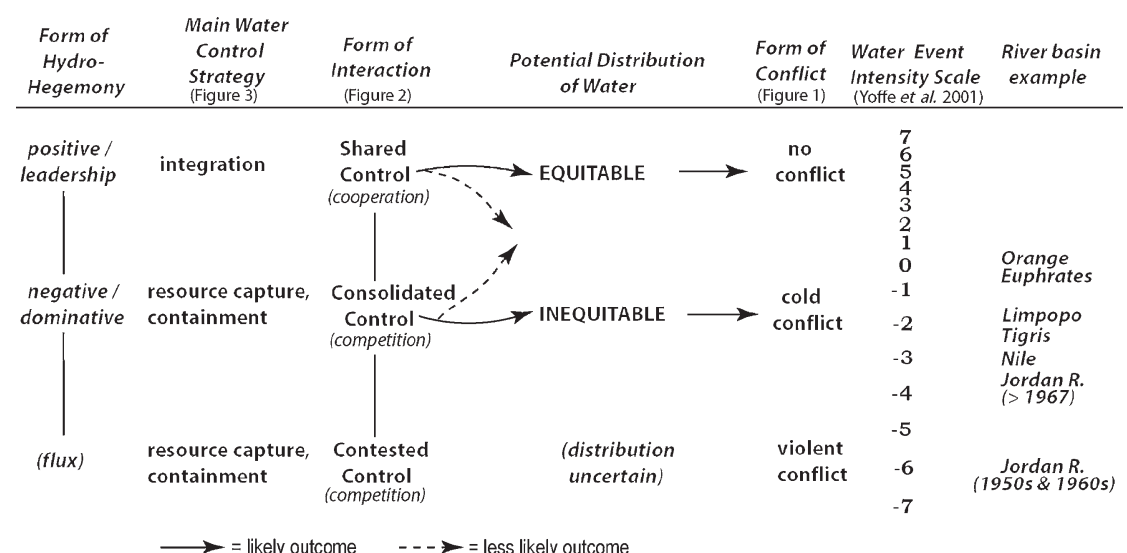

Fig. 5. The Framework of Hydro-Hegemony: combining the form of hydro-hegemony, form of interaction, outcome of interaction and intensity of conflict.

one water professional from non-hegemonic co-riparian Namibia. The dashed arrows of Figure 5 attempt to show that such apparent situations of stable shared control may also lead to inequitable outcomes.

The situation along the Jordan River is more extreme. It has cursorily been shown that Israel has achieved a negative/dominative form of hydro-hegemony through strategies of resource capture (with capture of territory in 1967) and containment (through the signing of treaties skewed in the hegemon's favour with Jordan and the Palestinians, as well as by coercion-pressure, securitization and military force employed to contain co-riparians Syria and Lebanon). One way that Israel maintains the consolidated control it has over the water resources is through the use of institutional structures set up in the 1995 Oslo II accords - the Israeli-Palestinian Joint Water Committee (JWC). Selby has described the Joint Water Committee as a tool more of domination than of cooperation (Selby, 2003b), one that ensures "joint mismanagement" of shared resources (Selby, 2005). An inequitable distribution of the water resources and an unresolved water conflict with its neighbours is the result.

Cases where the competition over water resources takes a violent form of conflict are likely to occur, according to Figure 5, when control over the flows is contested. This may occur when a weaker riparian gains in relative power (1st and 2nd dimension) vis à vis the hegemon and presents a real challenge to the status quo of hydro-politics. An example is Israel's comparative and very significant accumulation of power in relation to Syria and Jordan from 1948-67. The brief military clashes over water resources previously discussed occurred during this period of unstable relations. Israel's capture of the Syrian Golan and the West Bank in 1967 effectively consolidated its control over the resource and marked the beginning of the "Israeli hegemony era" (Feitelson, 2000: 350), a period of "contained instability" that exists until the present day.

\subsection{Other effects of hydro-hegemony - establishing the discourse}

The effects of this interplay of power, water and conflict are wide ranging. Aside from assuring itself the most secure and largest share of the scarce resource, the benefits of enjoying a position of hydrohegemony extend to determining the political discursive processes in each of the basins. 
By virtue of the hydro hegemon's greater economic and political power and as noted in the earlier citation of Waterbury, more of the decision-making positions in global-level think-tanks and lending institutions are populated by individuals from these states. International conferences, research centres, universities, regional policy-setting agencies and other institutions of intellectual and financial power likewise tend to be under-represented by people from Ethiopia, Uganda, Palestine, Syria or Iraq, for example, and disproportionately by representatives of the hydro hegemons.

National donor agencies seeking to assist the non-hegemonic states in "development" are readily caught-up in the broader humanitarian assistance dilemma of whether their assistance can do more harm than good. Obliged by diplomatic protocol and/or procedure to work within the existing asymmetric power relations, aid agencies by default invest in projects that can be built, rather than challenging the root political causes of the unequal status quo (Anderson, 2002: Chapters 1,4). An example is the dilemma faced by donors confronted with trying to ease conditions for Palestinian farmers affected by Israel's separation barrier being built inside Palestinian territory on the West Bank (PENGON, 2003; World Bank, 2003; Palestinian Hydorlogy Group, 2004). Re-establishing the transmission lines or wells cut-off by the passage of the barrier mitigates the damage, easing the impact on the individual farmer but granting a certain "consent" and permanence to the transgression. While an understanding that donor assistance is affected by the political process has led to attempts to work around the constraints (Swedish Ministry of Foreign Affairs (SMFA), 2001; ESCWA, 2004; Keating et al., 2005), most donors appear either unable or unwilling to fund projects that might challenge the hegemony, hydro or otherwise.

The efforts of the international water community are thus steered away from the injustice and inequity endured by the non-hegemonic states towards reinforcement of the status quo and perpetuation of the established discourse - as defined by the hydro-hegemon. Without exploring ways to address the imbalances created by the hydro-hegemony itself, which have been shown to be determined by power relations outside the water sector, the present and future for the state subject to hydro-hegemonized will remain determined by these power relations.

\subsection{Counter-hegemony}

Those states perceiving negative forms of hydro-hegemony may resort to a number of counterhegemony strategies to improve their situation. In seeking the ultimate goal of stable "shared control" of the resource with the hydro-hegemon (Figures 2 and 5), the non-hegemonic state will resort primarily to its agenda-framing (second-dimension) power. Such power, as we have seen, includes recourse to morality and international law, delay, de-securitization, issue linkage, economic development, alternative funding sources, negotiations and generation of positive-sum outcomes. The study of strategies to resist basin hegemony in the water sector is nascent, with ground-breaking work done most notably by Shapland (1997) and Cascao (2005). There is considerable scope for more work in this field.

In his consideration of just such countermeasures, Robert Keohane (1980) identifies the risks inherent with any upset of the given systems. He maintains that an unstable situation would benefit no side and indeed pollution or overexploitation of the trans-boundary resource is problematic to all parties. In the absence of a partner with whom to form a more cooperative approach, this may result in the weaker states taking "further action to hedge their bets, reducing their reliance on the hegemonical regimes and perhaps attempting to set up alternative arrangements of their own" (Collins, 2003: 14). 
This approach has indeed been adopted by individual farmers in Ethiopia in their efforts to build micro-dams, even on the tributaries to the Nile (see among others Homer-Dixon, 1999: 25). A similar analogy is found in rural Palestine where villagers engage in rooftop rainwater capture, away from the officials caught up in the water conflict. Even though they are carried out without the parties being aware of the theory of counter-hegemony, these acts take place primarily because there is little other choice. Such coping mechanisms, driven by the "mother of invention" - necessity - are prime examples of human ingenuity and adaptive capabilities (see McCaffrey, 2005; Woodhouse, 2005).

\section{Conclusion}

This study has emphasised two distinct features in the analysis of water conflict: (a) the effect of varying intensities of conflict and (b) the effect of power relations. It has been shown first, that even situations of conflict that fall short of war can have serious negative consequences on the hegemonized. Secondly, this study has stressed that the outcome in the competition over water resources is determined by the exertion of power of the hegemon. The frame of hydro-hegemony established herein provides a reasonably simple, comprehensive and testable analytical structure and an analytical tool for examining the options of riparians caught up in this interplay of water, power and conflict.

Hydro-hegemony theory posits that the hydro-hegemon can establish the form of interation over transboundary waters that it prefers. Whether the benefits of the established order endure for the hegemon and whether the weaker co-riparians benefit at all is the main concern of this analysis. The hydro-hegemon engaged in a guiding role in the basin can establish a positive/leadership form of hydrohegemony, likely through the execution of an integration strategy. The hydro-hegemon engaged in a unilateral, exploitative role is likely to establish a negative/dominative form of hydro-hegemony, likely through resource capture or containment strategies. Its control over the resource remains consolidated at the expense of its co-riparians and the perpetuation of an un-resolved conflict. Whether the hegemon chooses leadership or domination in the water sector is ultimately governed by the broader political context.

Each of these strategies may be carried out through the use of a range of compliance-producing mechanisms, or tactics, including military force, coercion-pressure, treaties, incentives, securitization, sanctioned discourse, and so on. Coercive resources available by definition in greater quantity to the hegemon include the ability to mobilize funds, a relatively greater political capital and preferred riparian position. The entire dynamic is set within an international context beset by inequitable outcomes including partisanship, global political trends and the absence of a universally-recognized international water law.

The hydro-politics in the Euphrates-Tigris, Jordan and Nile river basins have been used to apply the conceptual framework and test the theory. It has been shown that the three main strategies have been employed by the hydro-hegemons (Turkey, Israel and Egypt) at various moments resulting in the establishment of varying degrees of negative/dominative forms of hydro-hegemony. In all three basins there is evidence, sometimes extreme, of inequitable access to water resources being perpetuated.

A number of research issues have been raised by this preliminary exploration of hydro-hegemony. The most important of these relate to countering hydro-hegemony as a preliminary to resolving water conflicts. Considerable attention is merited in exploring how the hydro-hegemony framework may support the devices of international water law such as customary international trans-boundary water law 
and human rights law (see especially Frey, 1993 and Wolf, 2002). Anti-hegemonic resistance tactics such as the effect of time, of silence, the "cost of no agreement" and methods of issue de-securitization should also be explored.

Further refinement of the framework may be gained by testing it on river basins outside of the MENA region. The analytical approach can also be deployed to address trans-boundary water pollution issues, the hegemonic behaviour of multi-national corporations and to internal water conflicts. There is also utility in exploring links between hydro-hegemony theory and other water conflict theories, particularly those that address perception, symbolism, ideology and legitimacy (Gurr, 1970). The debate about who gets how much water, how and why is in need of these contributions.

\section{References}

Adam, B. (2004). The Hydropolitics of the Blue Nile Water Resources: A Case Study of the Impact of the Gezira Agricultural Scheme. Presentation made for King's College London Postgraduate Research Day, London.

Allan, J. A. (2001). The Middle East Water Question - Hydropolitics and the Global Economy, I.B. Taurus, London, UK.

Allan, J. A. (2003). IWRM/IWRAM a new sanctioned discourse? SOAS Water Issues Study Group Occasioinal Paper 50. SOAS/King's College, London.

Allan, J. A. (2004). Water in the Middle East - Understanding Conflict. Oxford Analytica. http://www.oxan.com/.

Allison, G. (1971). Essence of Decision - Explaining the Cuban missile crisis, Little, Brown, Boston, USA.

Anderson, M. B. (2002). Do No Harm - How Aid Can Support Peace - or War, Lynne Rienner Publishers, London, UK.

Barnett, C. (1999). Deconstructing context: exposing Derrida. Transcripts of the Institute of British Geographers, 24, 277-293.

Baylis, J. \& Smith, S. (1997). The Globalization of World Politics. An introduction to internal relations. Oxford University Press, Oxford.

Benvenisti, E. (2002). Sharing Trans-boundary Resources - International Law and Optimal Resource Use, Cambridge University Press, Cambridge, UK.

B'tselem (1998). Disputed Waters - Israel's Responsibility for the Water Shortage in the Occupied Territories (The Israeli Information Center for Human Rights in the Occupied Territories). Jerusalem, B'tselem.

Burawoy, M. (2003). For a sociological Marxism: the complementary convergence of Antonio Gramsci and Karl Polanyi. Politics \& Society, 31(2), 193-261.

Buzan, B., Waever, O. and de Wilde, J. (1998). Security - A New Framework for Analysis, Lynne Rienner Publishers, London, UK.

Cascao, A. (2005). Hydro Hegemony in the Nile River Basin, Presentation given at First Workshop on Hydro-Hegemony, 21/22 May 2005, King's College London, London, UK.

Chomsky, N. (1992). Manufacturing Consent - Noam Chomsky and the Media, Video documentary produced on DVD by Zeitgeist Video, Necessary Illusions Productions Inc., Mark Achbar \& Peter Wintonick.

Chomsky, N. (2003). Understanding Power: The Indispensable Chomsky, Vintage, London, UK.

Collins, R. O. (2003). The Inscrutable Nile at the Beginning of the New Millennium. University of California Santa Barbara, unpublished.

Cox, R. W. (1992). Towards a post-hegemonic conceptualization of world order: reflections on the relevancy of Ibn Khaldun. In Governance without Government: Order and Change in World Politics, Rosenau, J.N. and Czempiel, E.O. (eds), Cambridge University Press, Cambridge, UK, pp. 132-159.

CRS (2004). Foreign Aid: An Introductory Overview of U.S. Programs and Policy. Tarnoff, C. \& Nowels, L. Congressional Research Service, The Library of Congress. http://usinfo.state.gov/usa/infousa/trade/files/98-916.pdf.

Dahl, R. A. (1965). A Preface to Democratic Theory. University of Chicago Press, Boulder, USA.

Daoudy, M. (2003). Eau et pouvoir: la relation stratégique Irak/Turquie. Géostratégies, 2nd Semester 2005 (7), $99-118$.

Daoudy, M. (2005a). Turkey and the Region: Testing the links between power assymetry and hydro-hegemony, Presentation given at First Workshop on Hydro-Hegemony, 21/22 May 2005, King's College London, London, UK.

Daoudy, M. (2005b). Le partage des eaux entre la Syrie, l'Irak et al Turkie - Négociation, sécurité, et asymétrie des pouvoirs, CNRS Editions, Paris. 
Dellapenna, J. W. (2003). Water Rights and International Law. In The Iraqi Marshlands: A Human and Environmental Study. Clark, P. and Nicholson, E. (eds), Politico's, London, UK.

Delli Priscoli, J. (1998). Public involvement; conflict management; and dispute resolution in water resources and environmental decision making. Public Involvement and Dispute Resolution: A Reader on the Second Decade of Experience at the Institute for Water Resources. Creighton, J.L., Dunning, C.M., Delli Priscoli, J. \& Ayres, D.B (eds.). Institute for Water Resources, US Army Corps of Engineers, Alexandria, USA. IWR Report 98-R-5.

Dinar, S. (1999). The Israeli-Palestinian Water Conflict and its Resolution: A View Through International Relations Theory. International Studies Association 40th Annual Convention, Washington, DC, USA.

Dombrowski, I. (1998). The Jordan River Basin: Prospects for Cooperation Within the Middle East Peace Process. In Water in the Middle East: Potential for Conflicts and Prospects for Cooperation, Scheumann, W. and Schiffler, M. (eds), Springer, Heidleberg, Germany.

el Musa, S. (1997). Water Conflict - Economics, Politics, Law and Palestinian-Israeli Water Resources, Institute for Palestine Studies, Washington, DC, USA.

ESCWA (2004). Linking Aid to Development in the Current Palestinian Situation. Published for the Arab-International Forum on Rehabilitation and Development in the Occupied Palestinian Territory. UN Economic and Social Commission for Western Asia, Beirut, Lebanon.

Evans, G. and Newnham, J. (1998). The Penguin Dictionary of International Relations. Penguin, New York, USA.

Feitelson, E. (1999). Social norms, rationales and policies: reframing farmland protection in Israel. Journal of Rural Studies, 15 , $431-446$.

Feitelson, E. (2000). The ebb and flow of Arab-Israeli water conflicts: are past confrontations likely to resurface? Water Policy, 2, 343-363.

Fischhendler, I. (2004). Legal and institutional adaptation to climate uncertainty: a study of international rivers. Water Policy, 6(4), 281-302.

Frederiksen, H. D. (2003). Water: Israeli strategy, implications for peace and the viability of Palestine. Middle East Policy, $X(4)$ (Winter).

Frey, F. W. (1993). The political context of conflict and cooperation over international river basins. Water International, 18(1), 54-68.

Frey, F. W. \& Naff, T. (1985). Water: an emerging issue in the Middle East? The Annals of the American Academy of Political and Social Science, 482(1), 65-84.

GCI (2000). National Sovereignty and International Watercourses. Renens, Switzerland, Green Cross International. http://www.greencrossinternational.net/index.htm.

Gleick, P. (1995). Freshwater resources and international security. In Global Dangers: Changing Dimensions of International Security, Lynn-Jones S.M. and Miller S.E. (eds), MIT Press, Cambridge, USA.

Greco, F. (2005). The Securitization of the Disi Aquifer: A Silent Conflict between Jordan and Saudi Arabia, Presentation given at First Workshop on Hydro-Hegemony, 21/22 May 2005, King's College London, London, UK.

Gurr, T. R. (1970). Why Men Rebel, Princeton Press, Princeton, NJ, USA.

Hajer, M. A. (1997). The Politics of Environmental Discourse: Ecological Modernization and the Policy Process, Oxford University Press, Oxford Scholarship Online, Oxford, UK.

Heyns, P. (2005). "On Namibian-South African hydro-politics”, personal communication, London, UK. 20 May 2005.

Homer-Dixon, T. (1999). Environment, Scarcity and Violence. Princeton University Press, Princeton, NJ, USA.

Horrocks, C. (1999). Introducing Foucault, Icon Books, Cambridge, UK.

ICRC (1994). Handbook of the International Red Cross and Red Crescent Movement - International Humanitarian Law. International Committee of the Red Cross, Geneva, Switzerland.

Jägerskog, A. (2003). Contributions of regime theory in understanding interstate water cooperation: lessons learned in the Jordan River Basin. In Hydropolitics in the Developing World - A Southern African Perspective, Turton, A. and Henwood, R. (eds), African Water Issues Research Unit, Pretoria, South Africa, pp. 73-78.

Keating, M., Le More, A. \& Lowe, R. (2005). Aid, Diplomacy and Facts on the Ground: The Case of Palestine. Chatham House, London.

Keohane, R. O. (1980). The Theory of Hegemonic Stability and Changes in International Economic Regimes, 1967-1977. In Change in the International System, Holsti, O.R., Siverson, R.M. and George, A.L. (eds), Westview Press, Boulder, CO, USA, pp. $131-161$. 
Keohane, R. O. (1982). The demand for international regimes. International Organization, 36(2), 325-355.

Keohane, R. O. (1984). After Hegemony, Princeton University Press, Princeton, New Jersey, USA.

Kibaroglu, A. (2002). Building a Regime for the Rivers of the Euphrates-Tigris Rivers Basin. Brill, Netherlands, forthcoming.

Lorenz, F. M. and Erickson, E. J. (1999). The Euphrates Triangle: Security Implications of the Southeastern Anatolia Project, National Defense University Press, Washington, DC, USA.

Lowi, M. (1993). Water and Power - The Politics of a Scarce Resource in the Jordan River Basin, Cambridge University Press, Cambridge, USA.

Lukes, S. (2005[1974]). Power: A Radical View, 2nd edn. Palgrave MacMillan, Hampshire, UK.

Lustick, I. S. (2002). Hegemony and the riddle of nationalism: the dialectics of nationalism and religion in the Middle East. Logos, 1(3), (Summer) 18-44.

MacQuarrie, P. (2004). Water Security in the Middle East: Growing Conflict over Development in the Euphrates-Tigris Basin. Master's Thesis. Univerisity of Dublin, Dublin, Ireland. http://www.transboundarywaters.orst.edu/publications/ related_research/MacQuarrie2004_abstract.htm.

Mandela, N. (1994). A Long Walk to Freedom: The Autobiography of Nelson Mandela, Abacus, London, UK.

McCaffrey, S. C. (2005). The human right to water revisited. Water and International Economic Law. Brown Weiss, E., Boisson de Chazournes, L. \& Bernasconi-Osterwalder, N (eds.). Oxford University Press, Oxford, UK (forthcoming 2005).

McLean, I. and McMillan, A. (2003). Oxford Concise Dictionary of Politics, Oxford University Press, Oxford, UK.

Medzini, A. (2001). The River Jordan: Frontiers and Water, School of Oriental and African Studies, London, UK.

Naff, T. and Matson, R. (1984). Middle East water: the potential for conflict or cooperation. In Water in the Middle East Conflict or Cooperation?, Naff, T. and Matson, R. (eds), (Westview Replica Edition), Westview Press, Boulder, USA.

NATO (1999). Environment \& Security in an International Context - Final Report March 1999. Committee on the Challenges of Modern Society Report No. 232. Berlin, Germany, North Atlantic Treaty Organisation.

Newman, D. (2002). The Wazzani and our water problem. The Jerusalem Post, 18, September 2002.

Ohlsson, L. \& Turton, A. (1999). The turning of a screw: social resource scarcity as a bottle-neck in adaptation to water scarcity. SOAS Water Issues Study Group, School of Oriental and African Studies /King's College - London (Occasional Paper 19).

O'Tuathail, G. \& Agnew, J. (1999). Geopolitics and Discourse: Practical Geopolitical Reasoning in American Foreign Policy (Reprint from Political Geographical Quarterly (11) 190-204).

PENGON (2003). The Wall in Palestine - Facts, Testimonies, Analysis and Call to Action. Palestinian Environmental Non Governmental Organisation Network, Jerusalem.

Palestinian Hydrology Group (2004). Water for Life - Israeli Assault on Palestinian Water, Sanitation and Hygiene During the Intifada. Ramallah, West Bank, Palestinian Hydrology Group, European Community Humanitarian Office, Oxfam-Great Britain.

Selby, J. (2003a). Water, Power and Politics in the Middle East - The Other Israeli-Palestinian Conflict, I.B. Taurus, London, UK.

Selby, J. (2003b). Dressing up domination as 'cooperation' The Case of Israeli-Palestinian Water Relations. Review of International Studies, 29(1), 121-138.

Selby, J. (2005). Joint mismanagement: reappraising the Oslo water regime. Water for Life in the Middle East: 2nd IsraeliPalestinian International Conference, Antalya, Turkey, 20-12 October 2004, Israel/Palestine Center for Research and Information. http://www.ipcri.org/index1.html.

Shapland, G. (1997). Rivers of Discord: International Water Disputes in the Middle East, Palgrave Macmillan, Hampshire UK. Scientific Indian (2005). Who writes history. Available from: www.Thescian.Com/Blog/In, Issue: Sunday, February 6. 2005. Accessed June 2005.

SMFA (2001). Trans-boundary Water Management as an International Public Good - Executive Summary. Swedish Ministry for Foreign Affairs, Stockholm, Sweden.

Strange, S. (1987). The persistent myth of lost hegemony. In Authority and Markets - Susan Strange's Writings on International Political Economy, Tooze, R. and May, C. (eds), Palgrave Macmillan, Hampshire, UK.

Strange, S. (1994). Who governs? Networks of power in world society. In Authority and Markets - Susan Strange's Writings on International Political Economy, Tooze, R. and May, C. (eds), Palgrave Macmillan, Hampshire, UK.

Subedi, S. (2005) International Watercourse Law in Southeastern Asia. Presentation given at First Workshop on HydroHegemony, 21/22 May 2005, King's College London, London, UK, London Water Research Group. 
Takele, B. G. (2004). The Hydropolitics of Transboundary River Water Resources Development: The Case of the Blue Nile Basin in Ethiopia. Geography. Master's Thesis. King's College London, London.

Trottier, J. (1999). Hydropolitics in the West Bank and Gaza Strip. PASSIA - Palestinian Academic Society for the Study of International Affairs. Jerusalem.

Turton, A. (2003a). The political aspects of institutional developments in the water sector: South Africa and its international river basins. Department of International Politics, Faculty of Humanities. PhD thesis. University of Pretoria, Pretoria, South Africa.

Turton, A. (2005). Hydro Hegemony in the Context of the South African Cold War Experience. Presentation given at First Workshop on Hydro-Hegemony, 21/22 May 2005, King's College London, London, UK, London Water Research Group.

UN ILC (1997). Convention on the Law of the Non-navigational Uses of International Watercourses, United Nations International Law Commission.

Warner, J. (1992). The Politics of Diversion - Bridging troubled water in the Middle East. Master's Thesis submitted to the Department of International Relations. University of Amsterdam, Amsterdam, Netherlands.

Warner, J. (2004a) Mind the GAP - Working with Buzan: the Illisu Dam as a security Issue. SOAS Water Issues Study Group, School of Oriental and African Studies/King's College - London (Occasional Paper 67).

Warner, J. (2004b). Water, wine, vinegar and blood. On politics, participation, violence and conflict over the hydrosocial contract. Proceedings from Water and Politics Conference, 26-27 February 2004, Ch. 3, World Water Council, Marseilles, France.

Waterbury, J. (1997). Between unilateralism and comprehensive accords: modest steps towards cooperation in international river basins. Water Resources Development, 13(3), 279-289.

Waterbury, J. (2002). The Nile: National Determinants of Collective Action, Yale University Press, Ann Arbor, MI, USA.

Williams, P. (2002). Nile Cooperation through hydro-realpolitik? (Review of Taffesse 2001 and Waterbury 2001). Third-World Quarterly, 6(3), 1189-1196.

Wolf, A. T. (2000). "Hydrostrategic" territory in the Jordan Basin: water, war and Arab-Israeli peace negotiations. In Water in the Middle East: A Geography of Peace, Wolf, A. and Amery, H. (eds), University of Texas Press, Austin, USA.

Wolf, A. T. (ed.) (2002). Conflict Prevention and Resolution in Water Systems. The Management of Water Series. Elgar, Cheltenham, UK.

Wolf, A. T. (2004). Freshwater Trans-boundary Dispute Database. Oregon State University, Corvallis, OR, USA

http://www.transboundarywaters.orst.edu/.

Woodhouse, M. (2005). Threshold, reporting and accountability for a right to water under international law. Water Law Review, 8(1).

World Bank (2003). The Impact of Israel's Separation Barrier on Affected West Bank Communities. International Bank for Reconstruction and Development and the Local Aid Coordinating Committee, Jerusalem.

Yoffe, S. and Larson, K. (2001). Basins at Risk: Water Event Database Methodology (Basins at Risk Research Project Chapter 2). Corvallis, USA, Oregon State University.

Yoffe, S. B., Wolf, A. T. and Giordano, M. (2001). Conflict and Cooperation over International Freshwater Resources: Indicators and Findings of the Basins at Risk. Journal of American Water Resources Association, 39(5), 1109-1126.

Zeitoun, M. (2005). Pure water: secure or violated? Securitization, opportunitisation and violation along the Jordan River. Water for life in the Middle East. 2nd Israeli-Palestinian International Conference, Antalya, Turkey, 20-12 October 2004, Israel/Palestine Center for Research and Information. http://www.ipcri.org/index1.html.

Zisser, E. (2002). Israel and Lebanon: the battle for the wazzani. Tel Aviv Notes - An Update on Political and Strategic Developments in the Middle East, No. 50. Heller, M (ed.). Moshe Dayan Center for Middle Eastern and African Studies/Jafee Center for Strategic Studies, Tel Aviv University. Tel Aviv, Israel, October 2002. 
Annex A. Comparison of relative positions of hydro-hegemony achieved between riparians in selected MENA river basins.

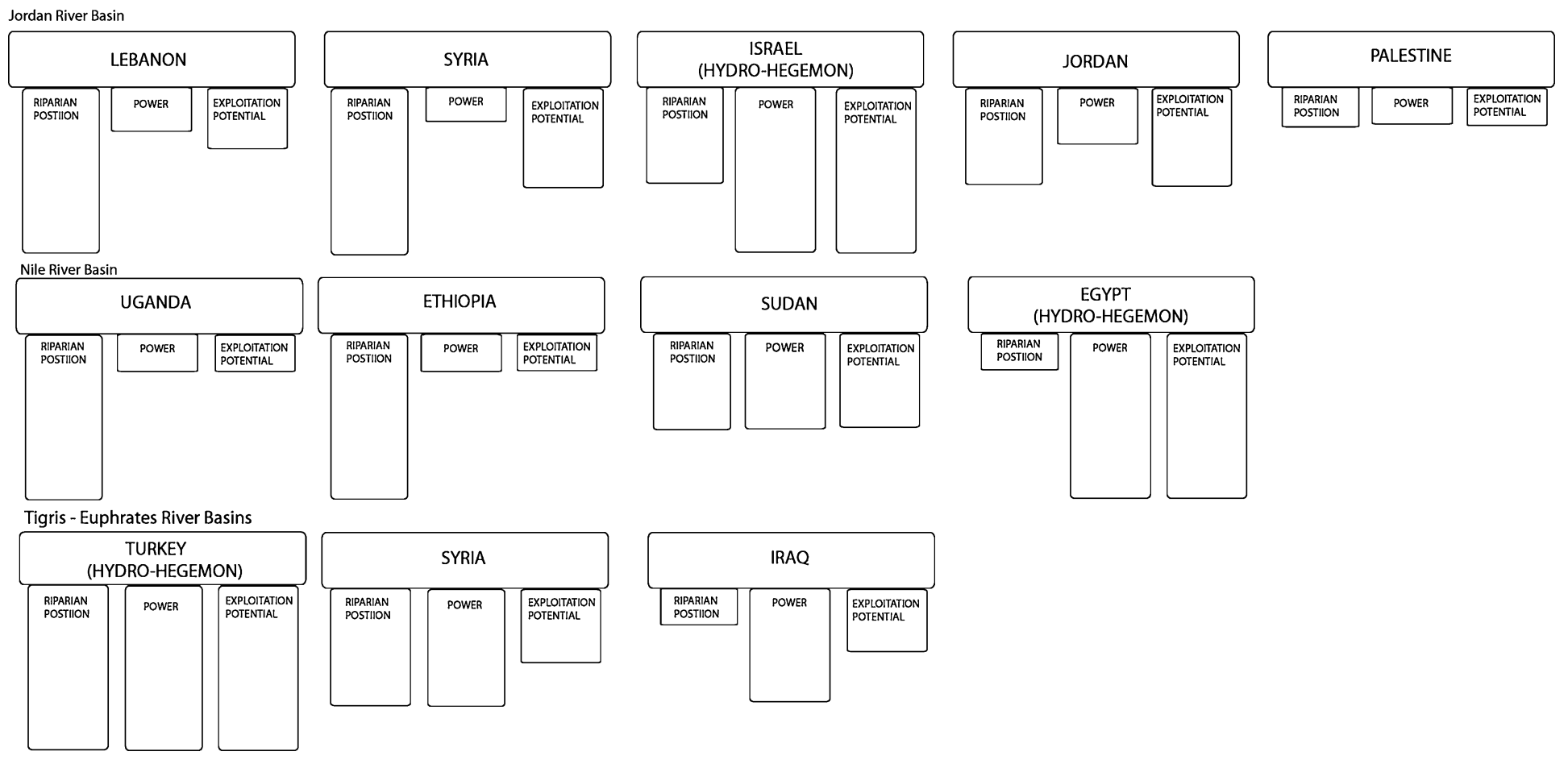

